\title{
The proposal of activities of pricing policy in the process of building and managing brand value in Slovak Republic
}

\author{
Križanová ${ }^{1}$ Majerová $^{2}$ \\ ${ }^{1}$ prof. Ing. Anna Križanová, CSc., University of Žilina, FPEDAS, KE, Univerzitná 1, 010 \\ 26 Žilina, Slovak Republic \\ ${ }^{2}$ Bc. Ing. Jana Majerová, PhD., University of Žilina, FPEDAS, KE, Univerzitná 1, 01026 \\ Žilina, Slovak Republic
}

\begin{abstract}
The article analyzes consumer's perception of the price of selected activities of policies that are implemented in the process of building and managing the brand value in the specific conditions of the Slovak Republic. Subsequently, the partial proposals for the pricing policy activities are formulated in specific stages of life cycle of brand in general.
\end{abstract}

Keywords: brand, branding, brand value, pricing policy

\section{Perceptions of selected activities of pricing policies by consumers in Slovakia}

For the perception of brand value the price is very important. In the foreign literature much attention is devoted to this issue. Formulated general concept of pricing policies is not applicated in the Slovak Republic for the particularities of national branding. These are mainly due to long-term action of mechanisms of centrally planned economies in the second half of the 20th century. For this reason, we have conducted a questionnaire survey on a representative statistical sample in the first quarter of 2012 to obtain information on the perception of marketing activities implemented in the branding process.

Questions about the pricing policy have been based on a complete concept of pricing policy activities of D. A. Aaker [1], K L. Keller [2] and A Štensova [3] and based on scientific publications focusing on consumer's preferences and product-line pricing strategies [4] and relationship between firm size and pricing policy [5].

The survey showed that customers consider more expensive products superior and the brand evokes a sense of prestige and social status improvement.

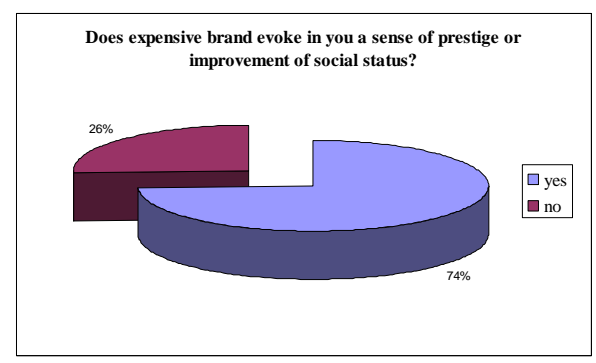

Fig. 1: Association of clients associated with more expensive brands

Different groups of customers are at different price levels within the category of production. From the perspective of branding is therefore extremely important to understand the total perception of the price by the customer of that brand. This 
should reflect the brand value from the customer's perspective. Such pricing should depend on how the customer sees and compares benefits of a branded product with the cost required for its acquisition and use.

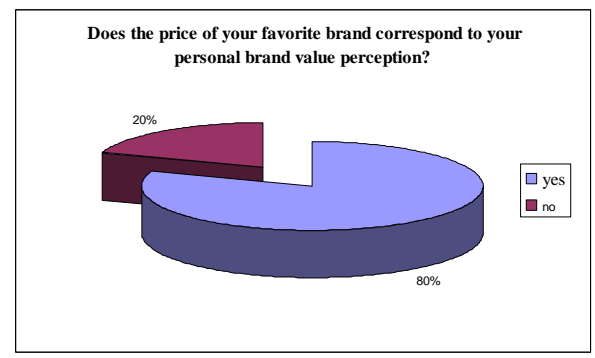

Fig. 2: Relationship of perceptions of price and its brand value

When first putting of brand we recommend to apply adaptive pricing policy, thus a policy that is based on adapting to competitive prices. Only when the customer begins to realize the value of the brand there is the moment when this price policy should be gradually replaced by active one.

Realized survey also showed that only a few customers remember the specific price of the product.

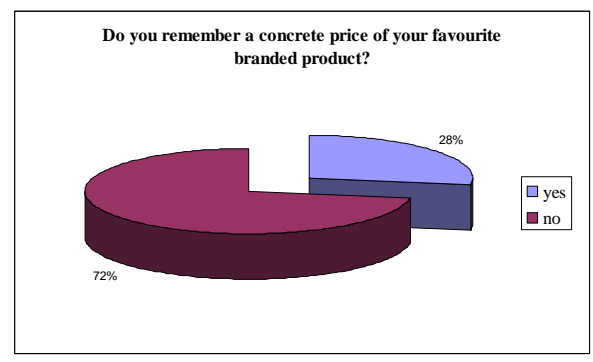

Fig. 3: The consumer's perception of price

We confirmed the findings of Chezy Ophir and S. Russell Winery [2] on the fact, that customer fixes more often socalled internal reference price in forms like a good price (how much a product should cost), typical price, final price, competitive price, the expected price in the future and so on in relation to a particular brand.

Knowledge of this internal reference price is especially important for managers in the transition from adaptive to active pricing policy. Unpleasant surprises that arise in comparation of perceived reference price and actual prices are likely to purchase a significant negative impact.

With brands which would provoke this effect by realization of price policy, we propose to apply the so-called alternative pricing strategies. Thanks to them, relatively more expensive brands may be seen as cheaper. There is a decomposition into smaller units of production. That means not only the amount of decomposition of the realized packaging policy, but also in the conversion of the final price in the sub-periods over the life of the branded product.

It is also appropriate in the context of positive and negative experiences to approach also to the issue of reductions. While these serve in the pricing policy as a tool to attract new customers of given brand, because they stimulate the buying decision of new customers, but they also negatively affect the perceived value of the brand by existing customers.

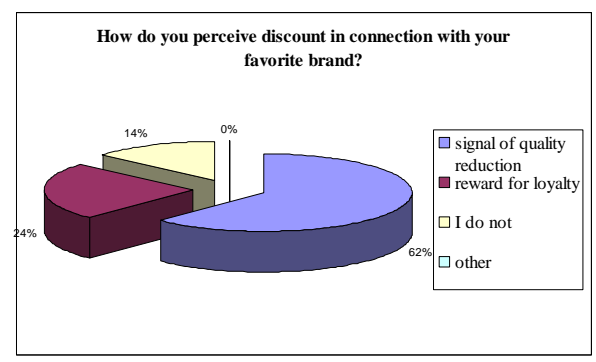

Fig. 4: Perception of reductions by consumers

Marketing activities under the pricing policy should be implemented with respect of the specific requirements that result of the characteristics of different phases of the life cycle of the brand. 
Among the existing theoretical approaches to the issue of brand life cycle is considered as one of the most comprehensive approaches appropriate for such an analysis the approach of G. Carona [3], which identifies five stages:

- introduction of a new brand on the market,

- confirm the potential of the brand,

- establishing the brand reputation,

- brand development,

- flight in orbit.

\subsection{Introduction of a new brand on the market}

When first putting of brand we recommend to apply adaptive pricing policy. This is based on the adaptation to competitive prices while respecting customer's preferences. Applying adaptive pricing policy in this phase of the life cycle is justified by the fact that currently exists on the market very few gaps. In practice, the condition often occurs that the brand enters the market, then it is necessary to create its own market share at the expense of competition. Realized questionnaire survey showed that most respondents reported the price as reason for a change in brand preference .

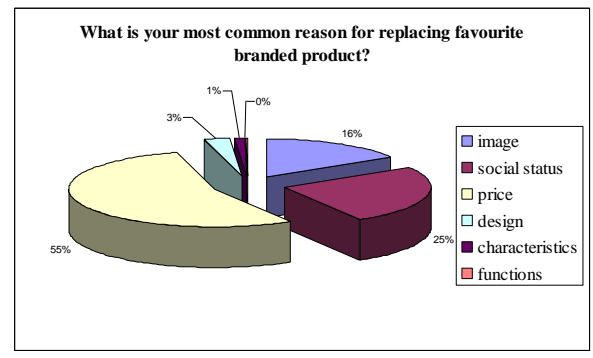

Fig. 5: Reasons for substitution of favorite brand

This tool of marketing mix is a key factor in changing perceptions of competitive operating brands, which affects the change in the structure of their market shares.

\subsection{Confirm the potential of the brand}

Pricing policy should be implemented in accordance with the concept of pricing policy from the phase of launching the brand on the market. An adaptive pricing policy within the existing customer's internal reference prices should be realized.

At the same time we consider that it is appropriate to consider at the end of this phase of the life cycle also the implementation of alternative pricing strategies. These stimulate the buying decision not only customers that have already decided but also new customers. These strategies are the substitution of Discount policy, which, however, from a psychological perspective on the customer acts as a signal to reduce the quality.

\subsection{Establishing the brand reputation}

At this stage of life cycle the pricing policy should move from adaptive to active. Price based on the active pricing concept should also move within the existing internal reference groups. Managers should always keep in mind the outcomes of the survey that cited the price as the most common reason for the substitution of a prefered brand.

In connection with the proposed major change in pricing strategy and customer sensitivity to pricing actions, we need alternative pricing strategies to be applied. The concept of setting a higher price compared to the competition and provide reduction could significantly impair the value of brands. Alternative pricing strategies with thier nature are gettig closer to the reduction policy but they produce different psychological effects.

\subsection{Brand development}

Pricing should be in our opinion, at this stage of the life cycle based on active and adaptive pricing strategy. Adaptive pricing strategy is appropriate in the new product line launched under the brand. 
We admit that so far perceived value of the brand makes the competitive advantage strong enough also for the realization of an active price policy but it is necessary to take into account that the most frequently reported reason for the substitution of popular brands, according to a questionnaire survey is the price.

Active pricing strategy should be implemented in the original product line where the brand has already built a desired competitive advantage based on the subjective perception of the value of the customer. For active pricing strategy in this phase of their life cycle applies the same as mentioned in connection with the pricing policy of the previous phase phase of establishing the brand reputation.

\subsection{Flight in orbit}

At this stage of the life cycle the pricing should be active in all product lines, not only those that are associated with that brand since its launch. Society-wide value of the brand is already so strong competitive advantage that adaptive pricing is not necessary to evacuate competitive customers. Again, it is necessary to respect the established custom internal reference group.

In relation to the concept of pricing policy we should emphasize the importance of effective functioning of marketing information system providing information about perceived value of a particular brand in a competitive comparison and about recognition of internal customer reference groups.

\section{Summary}

For the perception of brand value the price is very important. Consistent approach to pricing policy throughout the whole brand life cycle is not effective. This results from survey realized in Slovak Republic during first quarter of year 2012. This survey demonstrated that consumer's perception of price in Slovak Republic is different, so it is not effective to implement foreign concept of pricing policy in the process of building and managing brand value in Slovak Republic.

The article is an output of the Operational Programme Education, 26110230083: The Quality of Education and Development of Human Resources as pillars of the knowledge society, The Faculty of Operation and Economics of Transport and Communications, University of Žilina, Slovak Republic.

\section{References}

[1] D. A. Aaker, "Brand building budování značky," Brno: Computer Press, 312 p., ISBN 80-7226-885-6, 2003.

[2] K. L. Keller, "Strategické řízení značky,“ Praha: Grada Publishing, 796 p., ISBN 978-80-247-1481-3, 2007.

[3] A. ŠTENSOVÁ, "Manažment značky - vybrané problémy," Bratislava: Ekonom, 110 p. ISBN 80-225-2224-4, 2006.

[4] Draganska Michaela, Dipak C. Jain: "Consumer Preferences and ProductLine Pricing Strategies: An Empirical Analysis" in Marketing Science. Volume 25. Number 2, pages 164-174, ISSN 0732-2399, March-April 2006.

[5] Prabal Roy Chowdhury: "Firm size and pricing policy" in Bulletin of Economic Research. Volume 62. Issue 2, pages 181-195, ISSN 14678586, April 2010. 